\title{
TUDOMÁNYÁCAK A SZAKOSODÁS ÉS A POPULÁRIS KULTÚRA HATÁRÁN
}

MENNYIBEN BEFOLYÁSOLTA A MAGYAR FÖLDRAJZ- ÉS NÉPRAJZTUDOMÁNY FEJLÖDÉSÉT AFRIKA FELTÁRÁSA ÉS GYARMATOSÍTÁSA A 19. SZÁZAD MÁSODIK FELÉBEN?

\author{
KICSINDI EDINA
}

\begin{abstract}
Afrika földrajzi feltárása és gyarmatosítása a 19. század második felében nemcsak a mai értelemben vett tudományos és politikai kérdés volt, de a világról szerzett információk bővülése felé a nagyközönség is érdeklődéssel fordult: heti képes családi lapok, mint például a Vasárnapi Ujság (1854-1921), az évente három alkalommal megjelenö, széles spektrumú kulturális folyóirat, a Budapesti Szemle (1840-1944) rendszeresen közöltek híreket, képeket vagy nagyobb összefoglaló elemzéseket a kontinensen zajló eseményekről. Az alakuló tudományos társaságok ezt az érdeklődést kihasználva igyekeztek támogatókat biztosítani maguk és fejlődő tudományterületük számára. A tudományos ismeretterjesztés hőskora volt ez az időszak, amikor egy tudományos társaság felolvasó estjén részt venni családi programnak vagy társasági eseménynek számított. Ilyen körülmények között az 1872-ben létrejött Magyar Földrajzi Társulat (ma: Magyar Földrajzi Társaság) és az 1889-ben létrejött Magyarországi Néprajzi Társaság (ma: Magyar Néprajzi Társaság) alapvető céljaikat, feladataikat és tagsági viszonyaikat tekintve is eltértek a maiaktól, és éppen a 19. század végének utolsó néhány évtizede volt az az időszak, amikor fö tevékenységük lassan elmozdult az ismeretterjesztés felöl a tudományos müködés felé.
\end{abstract}

\section{Hány társaságra van szüksége a magyar társadalomnak?}

A korabeli tudományos társaságok egyfajta „hibrid” társaságok voltak, ahogyan azt Felix Driver is megfogalmazta a brit Royal Geographical Society kapcsán is (Driver, 2001: 24). Ez egybecseng Fodor Ferencnek a Magyar Földrajzi Társaság akkori szerepvállalásáról alkotott véleményével, vagyis, hogy „a Társaságnak kettős feladata és így végzetesen kettős arculata volt: egy befelé néző tudományos, és egy kifelé, a társadalom felé tekintő és nagy taglétszámot sóvárgó népszerủ arculat. Az utóbbi volt a tápláló, azért ez volt a hatalmasabb és erősebb.” (Fodor, 2006: 159). ${ }^{1}$ Ennek egyik oka a tudományterület fejlődésében keresendő, amely a minél szélesebb körben való elismeréséért és anyagi támogatásáért küzdött - számos rokontudománnyal egy idöben. A másik oka valószínüleg az a felfedezéseket kísérő hatalmas közérdeklődés 
lehetett a magyar olvasók részéröl, amely elöször talán a kortársakat is meglepte, de a 20. század első felének földrajztudós generációja már kemény kritikával illette a szenzációhajhászásnak behódoló Földrajzi Társaságot: „ezt a közönséget, ami összegyüjtötte, s a Földrajzi Közlemények első évtizedét sikeressé tette, az a magyar közönségnek az ismeretlen területekkel szemben való mohó érdeklődése volt. Ez szinte csodálatos, mert ahogy Teleki megjegyzi, kontinentális nép voltunk, s ilyennél ez szokatlan. Az egzotikum még élénken benne volt a kor érdeklődési körében." (Fodor, 2006: 131). A harmadik ok mindenképpen a szakemberhiányban keresendő, amely jobb híján vállaltan is az ismeretterjesztés irányába tolta el a Földrajzi Közlemények tartalmát (Kósa, 1989: 28). Ez a szakemberhiány eredményezte azt is, hogy a kevés, terepen szinte semmilyen tapasztalattal nem rendelkező szakemberek maguk is az egyébként széleskörü népszerüségnek és közfigyelemnek örvendő „földrajzi” utazókat tartották a legnagyobb tiszteletben és az ő munkásságukat követték figyelemmel - nem utolsó sorban az információhoz hozzájutásuk céljából.

A felfedezések korának magyar földrajztudománya ugyanakkor nem jelentett lemaradást a nyugat-európaihoz képest, Fodor szerint „talán egyetlen más idöszakban sem volt a magyar geográfiának olyan szoros kapcsolata a nyugat-európai tudományos körökkel, mint ekkor", és nagyjából az 1880-as évek közepére teszi a korszak lezárulását (Fodor, 2006: 137). A baj szerinte akkor kezdődött, amikor a Földrajzi Társaság az 1880-as évek végén, a már meghaladott ritteriánus irányzatot követő Hunfalvy János elnöksége alatt nem volt képes új utat kijelölni maga számára. ${ }^{2}$ „A felfedezések elfogytak, azokból már nem lehetett újabb szellemi tőkét kovácsolni, s felfedezőket előadásokra meghívni” - írja Fodor (Fodor, 2006: 144). Természetesen a Földrajzi Közlemények tanúsága szerint azért még előfordult, hogy híres utazó tette tiszteletét a földrajzi társaság felolvasóestjein - például Stanley vagy Oscar Baumann - de az 1880-as évek második felére ,a Ritter - Hunfalvy geográfia már veszített tekintélyéből" a szakmán belül, és Thirring Gusztáv az 1888. évi titkári jelentésében már arra panaszkodott, hogy a Társaság tagsága és az egyetemen a geográfus-hallgatók száma is csökkent (Fodor, 2006: 144).

Hunfalvy 1888-ban bekövetkezett halálát követően, 1891-től Lóczy Lajos elnöklete alatt indul meg a szakosodás a Földrajzi Társaságban. Lóczy 1893-ban feladta elnöki tisztét, és a következő hét évben a Társaság a laikus Erődi Béla vezetésével visszatérni látszott a népszerüsítő tevékenység elsődlegességének felvállalásához de miután 1900-ban ismét Lóczy lett az elnök, a budapesti egyetemi tanszék által elsőként kinevelt fiatal szakember-gárda segítségével megállíthatatlannak bizonyult a tudományterület specializálódása. A profilváltás azonban nem ment egyszerüen. A fiatal generációhoz tartozó Cholnoky Jenő, aki a Társaság titkáraként tevékenykedett Lóczy mellett, 1910-ben még mindig a népszerüsítő előadások nagy súlyáról panaszkodik az 1909-es évet összegző jelentésében: „Az előadások egynek kivételével népszerủek voltak. Ez nem a helyes irány. Nekünk nagy súlyt kellene fektetnünk arra, hogy szakszerü előadásaink is legyenek, mert a tudományos geográfiának nincsen nálunk semmiféle egyéb fóruma. A publikumot azonban hozzá kellene szoktatnunk, hogy szakszerü előadásokra ne jőjjenek el (sic!), mert ez az előadót 
kényelmetlen helyzetbe hozza, de viszont a laikus közönséget is untatja s elijeszti a Társaság előadásaitól." (Cholnoky, 1910: 157-158).

Cholnoky azonban tisztában volt azzal is, hogy a népszerüsítő előadások lényegesek a középosztály figyelmének - valamint a tagdíjakból származó anyagi támogatás - biztosítása szempontjából, ami az egyetlen lehetőséget jelentette a Földrajzi Társaság számára működésének fenntartására (Cholnoky, 1909: 146). Így tehát érthető, miért gondolták úgy az elnökségben, hogy a rokontudományok - például a néprajz - önálló társaságának megalapítása veszélyeztetheti a Földrajzi Társaság anyagi biztonságát, ha a még fiatal magyarországi középréteg számára alternatívát állít. A társaságok sorsa pedig szorosan összefüggött az általuk képviselt tudományterületek sorsával, mint azok társadalmi megnyilvánulási formái, egy olyan korban, amikor a frissen polgárosult társadalmi rétegek identitásának az egyesületi élet keretei adhattak gyakorlási lehetőséget.

\section{Tagsági viszonyok}

A szakemberhiány és a támogatási források szük volta általános problémát jelentett a 19. század utolsó és a 20. század első évtizedének tudományos társaságai számára - Kósa szerint nemcsak Magyarországon, de szerte Európában is. Szerinte „tudatosítanunk kell azt az ellentmondásos tényt, hogy a korabeli magyarországi társadalom - bizonyára nem társtalanul Európában - anyagilag erőtlen volt ahhoz, hogy tudományos társaságok sorát tagsági díjakból tartsa fenn, egyidejüleg azonban szellemi színvonala és igényei megkövetelték ezeknek a társaságoknak a létezését. Intellektuális kötelezettségekböl fakadó érzések, értelmiségi érdeklődés, hazafiság és társadalmi illem, nem kevésbé a sznobizmus egyaránt közrejátszottak a társasági tagságok toborzásában.” (Kósa, 1989: 26). A Néprajzi Társaság - a Földrajzi Társasághoz hasonlóan - ugyanezekkel a problémákkal küzdött a megalakulását követö első évtizedekben. A szakemberhiány miatt a társaság elnökségében és választmányában túlnyomó többségben voltak művészek, történészek, művészettörténészek, de találhatunk a névsorban földrajztudóst és politikust is (Kósa, 1989: 16). A szélesebb tagság a Földrajzi Társaságéhoz hasonlóan tanárokból, lelkészekből, állami tisztviselőkből, orvosokból, mérnökökből, jogászokból - és műkedvelő arisztokratákból állt (Kósa, 1989: 20). Sokan voltak tagjai mindkét társaságnak, és a századforduló néhány megjelent taglistáját átvizsgálva alaptalannak bizonyult a Földrajzi Társaság elnökségének azon félelme, hogy a fiatal néprajzi társaság nagy erőkkel szívja el híveiket - és így anyagi forrásaikat. A Magyar Földrajzi Társaság megalakulása után, 1873-ban - a tiszteletbeli tagokat nem számolva - 317 tagot számlált - ebböl 302 magánszemély és 15 intézményi tagság volt. ${ }^{3}$ Ez a taglétszám 20 év alatt, 1893as adatok szerint - szintén a tiszteletbeli tagokat nem számolva - 643-ra duzzadt, amely 548 fő magánszemélyi volt és 95 intézményi tagságot jelentett. ${ }^{4} \mathrm{Az} 1873$ as taglistához képest mindössze hét olyan személyt találtam, aki nem szerepelt az 1893-as taglistán - ám feltűnt az ehhez legkorábbi, közölt néprajzi társasági listán. A Magyar Néprajzi Társaság tagsága - tiszteletbeli tagok nélkül - 1894-ben 416 tagból állt, 340 magánszemélyi és 76 intézményi tagsággal. ${ }^{5}$ 
A taglisták lakóhely szerinti összetétele alapján végig nagyobb hányadban voltak a fővárosi tagok, mint a vidékiek, és a rendes tagok között - érthető kapcsolódás miatt - a Földrajzi Társaságban nagyobb számban találunk külföldi - vagyis a Magyar Királyság határain kívüli - tagokat, bár ez utóbbiba beletartoznak a Bécsben élő magyarok, főként arisztokraták is. A társasági élet (rendezvények, gyűlések, felolvasóestek) fövárosközpontú volt elsősorban, bár a Földrajzi Társaság a századfordulón már szervezett vidéki vándorgyűléseket is.

\section{A MFT magánszemélyi tagságának lakóhely szerinti megoszlása 1873-ban Taglétszám: 302 fö}

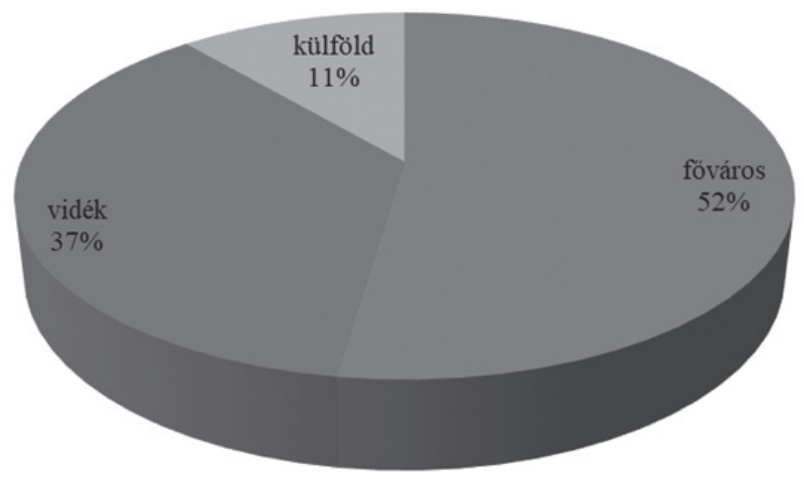

^ Forrás: A magyar földrajzi társulat tagjai. Földrajzi Közlemények 1 (1873): 67-73. pp.

\section{A MFT magánszemélyi tagságának lakóhely szerinti megoszlása 1893-ban Taglétszám: 548 fö}

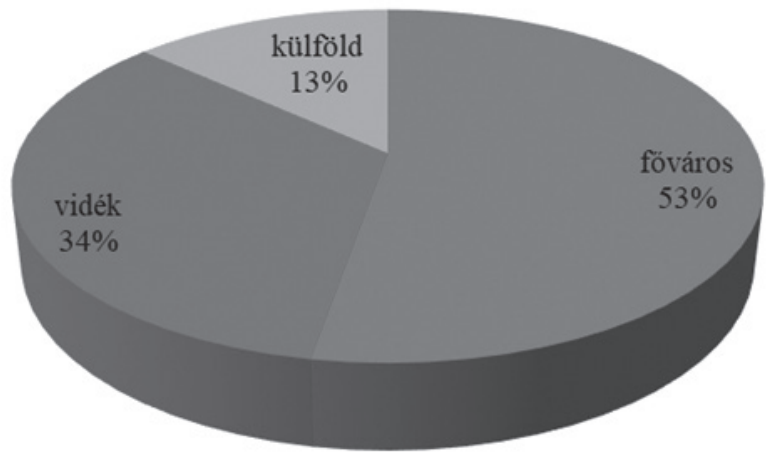

^ Forrás: A Magyar Földrajzi Társaság tisztikarának és tagjainak névjegyzéke az 1893. év elején. Földrajzi Közlemények 21 (1893): Melléklet. 


\section{A MNT magánszemélyi tagságának lakóhely szerinti megoszlása 1894-ben \\ Taglétszám: 340 fö}

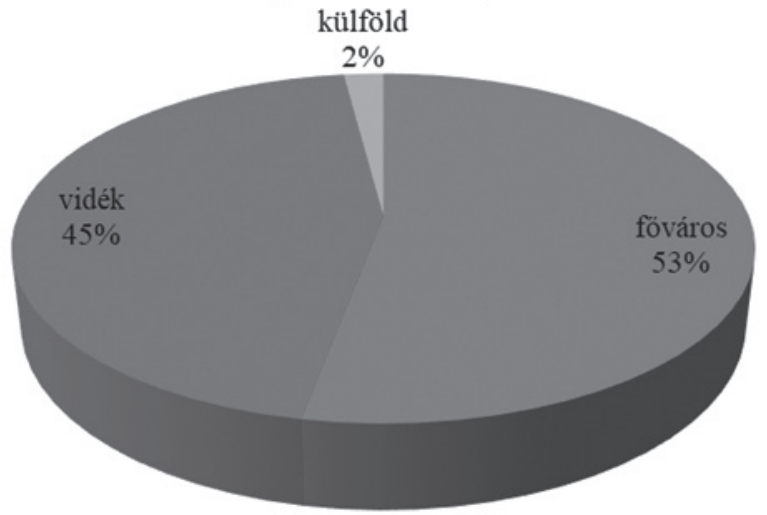

^ Forrás: Tagjegyzék. A Magyarországi Néprajzi Társaság Szervezete. Ethnographia 12 (1894): 216-222. $p p$.

A Néprajzi Társasággal kapcsolatban Kósa maga is kiemelte, hogy vidéki helyi körök nem szerveződtek a Társaság tevékenységéhez kapcsolódóan, de az elnökséghez érkeztek „különfajta indítványok” vidékről is, amelyek „sok újdonságot nem tartalmaztak", de mindenesetre mutattak némi tudományos társasági aktivitást a fővároson kívül is (Kósa, 1989: 20). Ennek ellenére a Néprajzi Társaság vidéki tagsága arányaiban nagyobb volt, és közel a tagság felét tette ki.

A magánszemélyi tagság foglalkozás szerinti megoszlása tekintetében a Magyar Földrajzi Társaság tagságának összetétele 1893-ban csak kis mértékben módosult az 1873-ashoz képest. A hivatalnokok aránya nőtt csupán valamennyivel, illetve szembetünő, hogy a vasúti és postai infrastruktúra növekedésével párhuzamosan nőtt a tagok között az alkalmazásukban dolgozók száma is. Ennek egyik oka az is lehet, hogy a Földrajzi Közlemények élénk figyelemmel kísérte a vasút- és távíró vonalak terjedését Európa-, Afrika- és Ázsia-szerte. A Magyar Néprajzi Társaság esetében viszont ilyen tagcsoporttal nem találkoztam, csakúgy, ahogy a Földrajzi Társaságnál tapasztalt csekély számú katonatiszti csoport is hiányzott - viszont nagyobbnak bizonyult az értelmiségiek aránya a szintén vizsgált magánszemélyi tagsággal rendelkezők körében. A vasúti és postai dolgozók száma a hivatalnok-csoport 18\%-át tette ki 1893-ban. 
A foglalkozási kategóriákat a következőképpen határoztam meg a taglisták elemzésekor:

\begin{tabular}{|c|c|c|c|c|c|}
\hline értelmiségi & vállalkozó & hivatalnok & birtokos & arisztokrata & katona \\
\hline orvos & kereskedö & képviselö & földbirtokos & föherceg & (tisztek) \\
\hline jogász & iparos & alispán & nagybirtokos & gróf́nö & \\
\hline mérnök & magánzó & távírász & birtokos & báró & \\
\hline tanár & & tanácsos & & érsek & \\
\hline tudós & & alkalmazott & & püspök & \\
\hline egyházi személy & & jegyző & & herceg & \\
\hline hallgató & & tanfelügyelő & & & \\
\hline rabbi & & bíró & & & \\
\hline múvész & & & & & \\
\hline
\end{tabular}

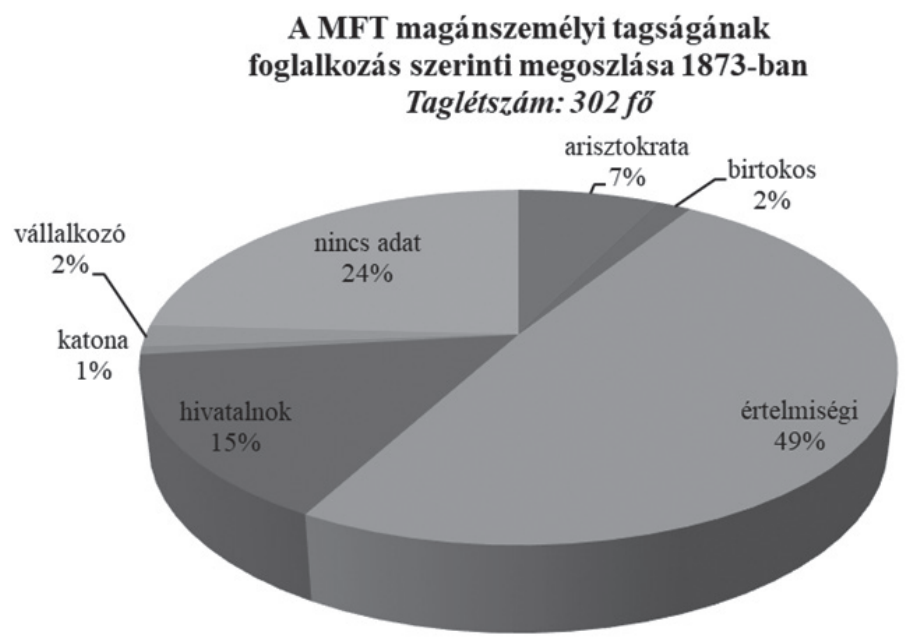

^ Forrás: A magyar földrajzi társulat tagjai. Földrajzi Közlemények 1 (1873): 67-73. pp.

A magánszemélyi tagság nem szerinti megoszlása további érdekességeket mutat. Annak ellenére, hogy az 1873 és 1893 között eltelt húsz esztendőben az iskolázott és értelmiségiként önálló munkakört betöltő nők száma növekedett Magyarországon, a Magyar Földrajzi Társaság tagjai között 1873-ban több női nevet figyelhetünk meg, mint 1893-ban. Míg 1873-ban a tagok 16\%-a volt nő, addig ez az arány 1893-ra mindössze 3\%-ra csökkent - ami viszont pontosan megegyezett a Magyar Néprajzi Társaság 1894-es női tagságának arányával. Az 1873-as tagságban többször is találkozunk olyan esettel, hogy egy házaspár mindkét tagja szerepel a taglistán, de a nők viszonylag magasabb aránya az 1893-as tagsághoz képest a Földrajzi Társaság - és így a tudomány specializálódásával is magyarázható. 
A MFT magánszemélyi tagságának

foglalkozás szerinti megoszlása 1893-ban

Taglétszám: 548 fö

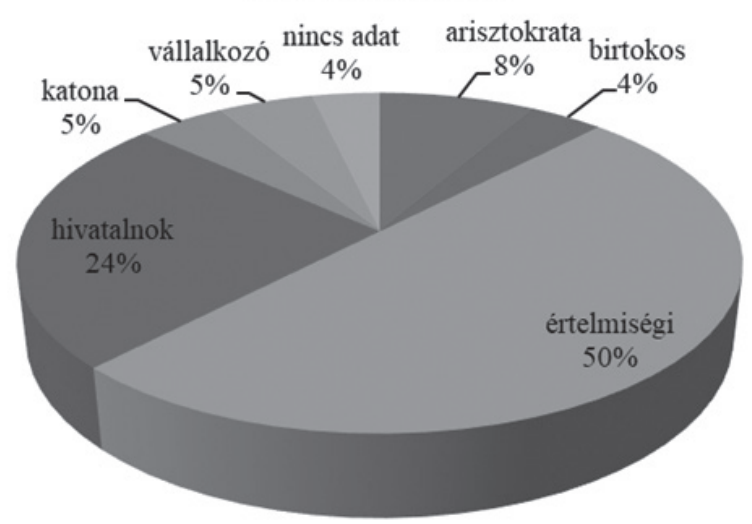

\Forrás: A Magyar Földrajzi Társaság tisztikarának és tagjainak névjegyzéke az 1893. év elején. Földrajzi Közlemények 21 (1893): Melléklet.

\section{A MNT magánszemélyi tagságának foglalkozás szerinti megoszlása 1894-ben Taglétszám: 340 fö}

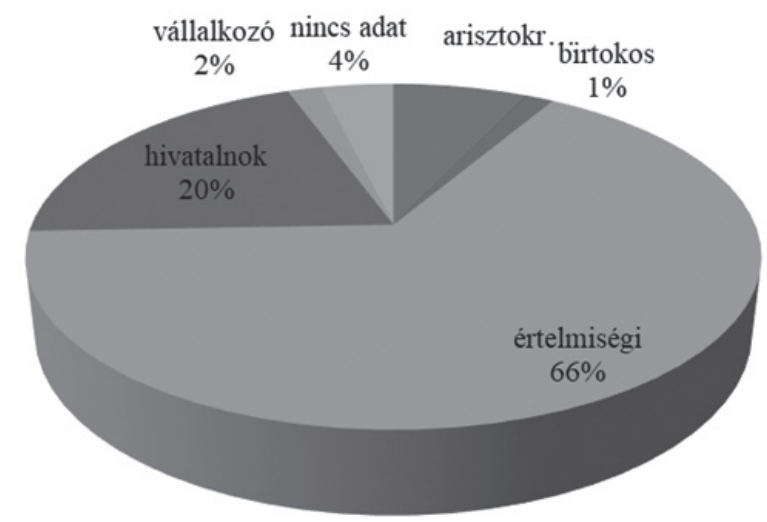

Forrás: Tagjegyzék. A Magyarországi Néprajzi Társaság Szervezete. Ethnographia 12 (1894): 216-222. $p$. 
Azt, hogy a társaságok által terjesztett információk valójában kikhez jutottak el, milyen széles körben terjedtek, lehetetlen megbecsülni a taglisták alapján. A tagok természetesen rendszeresen megkapták a folyóiratokat, ám azokat valószínüleg a családjuk, szomszédságuk is olvashatta, a kor újságolvasási szokásainak megfelelően. A Földrajzi Társaság esetében a nyilvános előadások, társasági rendezvények nagy része pedig - esetleg belépti díj ellenében - nyitva állt a tagsággal nem rendelkező, érdeklődő nagyközönség számára is, amelyen akár gyerekek is részt vehettek. Ezeket a nyilvános előadásokat rendszeresen meghirdették az országos lapokban, például a Vasárnapi Ujság oldalain, amely egyébként is élénk figyelemmel kísérte a Társaság müködését. Ennek egyik oka az is lehetett, hogy a szerkesztőségből többen is - pl. Sámi Lajos - a Földrajzi Társaság választmányi tagságában is helyet kaptak. 1873-ban például így hirdette a lapban egyik korai, vasárnap délelőtti előadását, amelyet valószínüleg azért is tettek ilyen időpontra, hogy az érdeklődők egyfajta családi kikapcsolódásként tekintsenek a Társaság rendezvényeire: ,a magyar földrajzi társulat f. hó 16-án vasárnap délelötti 11 órakor az akadémia palotájában gyülést tart, melyen következő felolvasások fognak tartatni: »A földrajzi tudomány jelen állásáról« Hunfalvy Jánostól. »Livingstone felfedeztetése Stanley által« Sámi Lajostól. Az alapszabályok értelmében a társulat ily gyülésein nem tagok bemeneti dijat fizetnek. Bemeneti jegyek Aigner Lajos könyvkereskedésében (a váczi-utczában), s a gyülés napján az akadémia kapusánál kaphatók. Személyjegy ára $50 \mathrm{kr}$, családjegyé - 5 személyre - 1 frt. A társulati tagok fölkéretnek, hogy évjegyüket magukkal hozzák."

A nyilvános előadások nyomait az 1890-es évek elejéig találhatjuk meg a Vasárnapi Ujságban. A Társaság keretében szervezett felolvasások alkalmával a Társaság tagjai tartottak tájékoztató előadásokat többek között az afrikai felfedezések előrehaladásáról is, ${ }^{7}$ vagy ritkán egy-egy híres utazót kértek fel élményeik tolmácsolására. ${ }^{8}$ A Budapesten vendégeskedö külföldi utazók általában a Társaságon kívül is tartottak előadásokat, így előfordult, hogy a Földrajzi Társaság ülésein tett látogatásaik a tagság szükebb körének szánt rendezvények lehettek, és ezzel a szakmaiság megnyugtató benyomását kelthették az útkereső tudomány hívei szemében. ${ }^{9}$

\section{A kérészéletủ Magyar Afrika-Bizottság}

A Magyar Földrajzi Társaság a legnagyobb sajtófigyelmet azonban kétségkívül a kérészéletủ Magyar Afrika-Bizottság müködésének néhány éve alatt élvezhette. A Bizottság előzményei II. Lipót belga király védnöksége alatt a „középafrikai kutatások érdekében tartott brüsszeli kongresszus"-ig nyúlnak vissza, amelynek elsődleges célja volt „eszközöket és utat-módot keresni és találni arra, hogy lehetne meghonosítani a polgárosodást Közép-Afrikában, földgömbünk azon egyetlen részén, a hová az mindeddig nem hatott, hol a fetisimádásnak hódolnak, $\mathrm{s}$ ünnepélyek alkalmával még most is embereket áldoznak, és hol a fökereskedési czikket az ember képezi." ${ }^{10}$ A Földrajzi Társaságot a kongresszuson gróf Zichy Edmund képviselte, aki miután a Társaság október 19-ei ülésén beszámolt a rendezvényröl, indítványozta, hogy a Magyar Földrajzi Társaság is csatlakozzon Lipót kezde- 
ményezéséhez, és hozzon létre egy Afrikával foglalkozó bizottságot. A Földrajzi Társaság még ebben az évben tiszteletbeli taggá választotta II. Lipótot. A Vasárnapi Ujság egészen a kezdetektől nagy érdeklődéssel követte a Bizottság munkásságát, arról is hírt adott, hogy a „,belga király táviratilag köszönte meg dr. Hunfalvy Jánosnak a földrajzi társaság elnökének, tiszteletbeli taggá megválasztását. Egyszersmind utasitotta bécsi követét, hogy tegye magát érintkezésbe a m. kir. földrajzi társasággal a nemzetközi expediczió ügyében, melynek a király elnöke."'11 A Magyar Afrika Bizottság végül 1877. május 15 -én tartotta alakuló ülését. ${ }^{12}$ Díszelnökének a jelentős magyarországi birtokokkal rendelkező Fülöp szász-coburg-gothai herceget kérték fel, aki nem mellesleg II. Lipót veje is volt egyben. A Bizottság tényleges ügyvivő elnöke Haynald Lajos kalocsai érsek lett, akinek a kontinenst civilizálni szándékozó mozgalmak iránti elköteleződését mi sem bizonyítja jobban, minthogy támogatásával jutottak el néhány év múlva az első magyar misszionáriusok Afrikába. ${ }^{13}$

A magyarországi Afrika-Bizottság léte lehetőséget teremtett az afrikai utazások iránt most a legfogékonyabbnak mutatkozó, magyarul olvasó közvélemény számára itthon is, hogy közvetlenül bepillanthasson egy nagyszabású expedíció előkészületeibe, vagy akár részese lehessen a nagy kalandnak. A Földrajzi Közlemények 1877-ben például úgy kommentálja ezt a megnövekedett érdeklődést, hogy „,napjaink legörvendetesebb jelenségeihez tartozik azon fokozódó érdeklődés, melyet a nagy közönség most a nemzetközi afrika-társulat (sic!) müködése és szent czélja iránt tanúsít", ${ }^{14}$ és felhívja a figyelmet arra is, hogy a Bizottság rendezvényeit különösen sok nő látogatja. ${ }^{15}$ Ez egybecseng azzal, amit az 1873 -es év taglistája is tükröz, miszerint az 1870-es években sokkal nagyobb volt az érdeklődés a nők körében a Földrajzi Társaság tagsága iránt, mint az 1890-es években, és hogy ennek oka a felfedezések korához kapcsolódó ismeretterjesztő, „divatos témájú” előadásoknak köszönhetö leginkább.

A legnagyobb hatással azonban az bírt, hogy a belga király Közép-Afrikába tervezett expedíciójához Budapesten is nyílt felhívás keretében várták a csatlakozni vágyó „bátor és tudományos” utazókat (Sámi, 1877: 679). A felhívásra a korabeli lapok híradásai szerint mintegy kétszázan jelentkeztek. ${ }^{16}$ Zömében mérnökök, vasúti mérnökök, grafikusok, ${ }^{17}$ de a jelentkezők között volt például a festő Feszty Árpád is. ${ }^{18}$ A jelentkezők között azonban nehéz volt találni olyat, aki a brüsszeli bizottság által elvárt „tudományos képzettséggel” rendelkeztek volna, ezért a felhívást még egyszer közzé kellett tenni. ${ }^{19}$ Végül egy mérnököt ajánlottak a belga szervezők figyelmébe, hogy a Magyar Afrika-Bizottságot képviselje az expedíció során. ${ }^{20}$

A Bizottság munkája azonban nem tartott sokáig. Még a Földrajzi Társaságon belül is utólag úgy értékelték, hogy „nagyobb lármával alakult meg, mint a menynyit müködött” (György, 1882: 781). A közép-afrikai belga expedíció magyar részvételéről szóló hírek lassan elhalványultak a lapokban, párhuzamosan a „belga” gyarmatosító törekvésekröl szóló hírek felerösödésével. A Kongó-medencével kapcsolatos kezdeti, lelkesítő „mindannyiunké-érzés” hamarosan visszaváltozott az eseményeket csak a kívülállók szemével követni tudók ujjongásává a Vasárnapi Ujság és a Földrajzi Közlemények hasábjain is. A Kongó-medencéböl és Stanley 
tevékenységéről érkező nyugtalanító hírektől való lassú elhatárolódás jele is volt ez. A Magyar Afrika-Bizottságot végül elérte a csendes végkimúlás, hagyatékának mindössze $5 \mathrm{db}$ záloglevél - felosztásáról egy eldugott hír számolt be csupán. ${ }^{21}$

\section{Tudomány és ismeretterjesztés}

Ezzel szemben Magyar Néprajzi Társaság rendezvényei a megalakulását hirdető felhívástól eltekintve jóval kevesebbszer kaptak helyet a Vasárnapi Ujságban. ${ }^{22}$ A Néprajzi Társaság megalakulása közel volt már ahhoz a korszakhatárhoz, amikor az 1890-es évek közepére lassan megfogyatkoztak a professzionalizálódó társaságok széles körü közönséget megmozgató előadásai. A korabeli sajtó nemcsak a társaságok munkáját figyelte, közvetlenül is gyüjtött információkat a tudományos ismeretterjesztés jegyében. Ez mindenképpen valós igényt sejtet a háttérben, és a kortársak szemében az 1880-as évek közepén a tudományos folyóiratok és az ismeretterjesztő hetilapok között jól látható határ húzódott: ,a tudós, ki a szaklapok közleményeiből tanulmányozza azon buzgó kutatások eredményét, melyek Afrika bensőjét felderíteni czélúl tüzték, mint a mủvelt közönség, mely a hirlapok hasábjain gyakran talál érdekes tudósításokat a bátor utazók sikereiröl.” (Tömösváry, 1886: 309) A fentiek alapján azonban a határ nem volt ilyen éles. Az idézett szerző, aki gyakran publikált a Földrajzi Közlemények oldalain, maga is hivatalnok volt, aki érdeklödve figyelte az afrikai „kutatások” elörehaladását. Mai szemmel nézve tehát éppoly mükedvelő lehetett csupán, mint a Vasárnapi Ujságban és a Földrajzi Közleményekben egyaránt publikáló „tudós emberek” többsége a korban - például Sámi Lajos vagy György Aladár -, de tevékenysége tökéletesen illeszkedett a kor tudományos életébe, hiszen a tudományos élet is a társasági életen keresztül a mainál jobban integrálódott a társadalmi keretek közé. Amíg ma a tudományos eredményeknek és információknak a társadalom felé visszacsatornázása jelenti az egyik legnagyobb kihívást tudósoknak és tudománypolitikával foglalkozóknak egyaránt, addig a 19. század utolsó harmadában ez jól működött, és a problémát inkább a fiatal, már képzett tudósgeneráció számára éppen ennek mértéke jelentette, mert a szakmai munka kárára engedett teret az ismeretterjesztésnek. A Vasárnapi Ujság évtizedeken keresztül sikeresen látta el a kirótt feladatot, még jóval azután is, hogy a századfordulót követően a szaktársaságok értesítői kevésbé engedtek teret az ilyen írásoknak és híreknek. Kiadványai segítségével hetente széles körben, és ami nagyon fontos, képi formában is terjesztette az új tudományos eredményeket az újdonságra, a misztikumra és az egzotikumra fogékony olvasók számára. Mivel információi nagy részét lapszemle útján szerezte be külföldröl, a munkatársaknak nem jelentett problémát a külföldi társaságok értesítőinek átnézése sem, hogy friss és érdekes hírekhez juttassák olvasóikat. $^{23}$

\section{A populista felfedező: Sir Henry Morton Stanley (1841-1904)}

Stanley munkásságát sokkal vegyesebben ítélték meg a kortársak, mint David Livingstone-ét. Úgy tủnik, hogy éppen az a felfokozott sajtóérdeklődés okozta közvetve hírnevének csorbulását, amely megajándékozta a Livingstoné-nál nagyobb 
Henry Morton Stanley 1841-ben született John Rowlands néven brit alattvalóként a walesi Denbighben. Dolog- és árvaházakban nött fel, 18 éves korában az Egyesült Államokba ment, ahol harcolt a polgárháborúban (mindkét oldalon), majd tengerészként és újságíróként kereste megélhetését. 1867-től a New York Herald levelezőjeként már az abesszíniai háborúról tudósított. 1868-ban kapta azt a megbízatását, hogy keresse meg David Livingstone-t. A Nílus forrását kereső skót misszionáriusról és felfedezőről 1866 óta nem érkezett hír. Stanley 1871 novemberében találkozott Livingstone-nal Ujijiben (Tanzánia). Utazásáról 1872-ben jelent meg How I Found Livingstone címü könyve, amely magyarul teljesen 1944-ben jelent meg Hogyan találtam meg Livingstonet címmel.

1873-ban, Livingstone halálát követően, mintegy örököseként fellépve folytatni tervezte Közép-Afrika feltárását. Ehhez a New York Herald és a brit The Daily Telegraph nyújtott támogatást. 1874 és 1877 közötti utazásairól 1878-ban jelent meg könyve Through the Dark Continent címmel, amely magyarul 1883-ban jelent meg Utazásom Közép-Afrikában címmel. Mivel a briteket nem érdekelte a Kongó-medence civilizálásával (értsd: fejlesztésével - vasúti és vízi közlekedési útvonalak fejlesztése a nyersanyagforrások elérése biztonságos szállítása céljából), Stanley a belga királyhoz, II. Lipóthoz fordult, aki további anyagi támogatást biztosított számára. Stanley 1879-1884 között folytatta tevékenységét Afrikában II. Lipót megbízásából, ennek eredményeként jött létre Kongó Szabad Állama, amely II. Lipót magántulajdonaként nyert elismerést az európai nagyhatalmak által. Utolsó afrikai útja során, 1887-1889 között kereste fel Emin Pasát a mai Uganda területén, amellyel hozzájárult a brit befolyás növekedéséhez a területen. Az utazásról szóló In Darkest Africa címü könyv 1890-ben jelent meg, 1891-ben pedig a magyar fordítása is A legsötétebb Afrikában címmel. Stanley 1890-től 1904-ben bekövetkezett haláláig Európában élt brit alattvalóként és utazásairól előadókörutak keretében tartott előadásokat - több-kevesebb sikerrel.

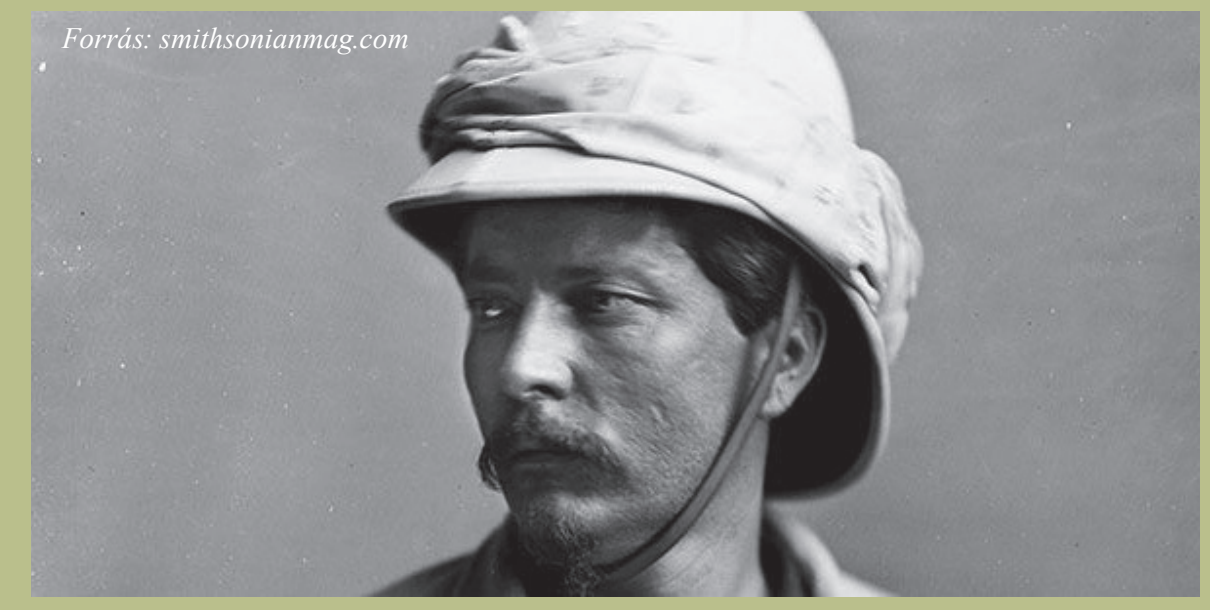

Kicsindi Edina: Tudományágak a szakosodás és a... 
ismertséggel. Stanley maga újságíró volt, a belga király megbízásától eltekintve útjai sajtóexpedícióknak voltak inkább mondhatók, így a szakmai társaságok - sem a missziós társaságok, sem pedig a földrajzi körök - nem ismerték el tevékenységét. Bár a magyar sajtó is - mind a Földrajzi Közlemények, mind pedig a Vasárnapi Ujság - méltató szavakkal szólt róla eleinte, „kiváló férfiư”-nak ${ }^{24}$ és „,bátor utazó”nak $^{25}$ nevezve, 1890-re hozzánk is eljutott az öt ért kritikák híre.

Az első kritikus hangok Nagy-Britanniában 1872-ben, első könyve megjelenésének évében csattantak fel. Ekkor vett részt Brightonban a Royal Geographical Society egyik összejövetelén, amelyen - bár a Társaság meghívására érkezett a brit földrajzi körök elutasították munkásságát, sőt, múltjában is kutakodni kezdtek, hogy támadási felületet találjanak hírneve csorbítása érdekében. Felix Driver szerint a „legtöbb kritikusa számára Stanley a felfedezések új, szemtelen megközelítésének szimbóluma volt. Földrajzi körökben egyszerüen fenyegetést láttak stílusában, amely a populáris, fogyasztói és szenzációhajhász földrajzot ígérte. Az Exeter Hall [a miszsziós társaságok] számára módszere semmi máshoz nem vezetett, csak háborúhoz, illetve ahhoz a világszemlélethez, amely az 1880-1890-es évek új imperializmusának legrosszabb vadhajtásává sarjadt. Stanley földrajzi és filantróp kritikái egyetlen pont körül összpontosultak, amely a felfedezésekkel és a birodalommal kapcsolatos viták szimbolikus középpontja is volt egyben: Livingstone mítosza. A kortársak szemében Stanley minden volt, ami Livingstone nem.” (Driver, 1991: 147-149, 164-165)

A botrány azonban csak 1890 körül robbant ki körülötte, amikor az Emin pasaféle expedíció több részvevője is - például E. M. Barttelot naplója alapján a bátyja, vagy Theodor Westmark - a bennszülöttekkel és az expedíció tagjaival szembeni erőszakos magatartását tárta a világ elé. ${ }^{26} \mathrm{~A}$ magyar földrajzi körök és az újságolvasó rétegek azonban felfokozott várakozással tekintettek az angol kiadással szinte egy időben magyarul is megjelenő újabb könyvére. ${ }^{27}$ A közfigyelem Livingstone útjaihoz hasonlóan Stanley útjait is aggódóan követte, többször is halálhírét költötték ${ }^{28}$ de a hazatérte és az expedícióról beszámoló $A$ legsötétebb Afrikában címü könyve minden korábbi afrikai utazó által élvezett sajtófigyelmet felülmúlt. Köszönhető volt ez többek között annak is, hogy ez az expedíciója a Livingstone-hoz kapcsolódó első útjához nagyon hasonlóan alakult. A felkeresett személy most Mehmet Emin Pasa (Isaak Eduard Schnitzer) volt, a mai Szudán területén fekvő, az akkor egyiptomi fennhatóság alatt álló Equatoria tartomány kormányzója, akinek tartományát a Mahdi-felkelés elvágta a külvilágtól. ${ }^{29}$ A konfliktusba beavatkozó briteket kísérő rendkívüli európai sajtófigyelem közepette az „Emin Bey fölszabadítására induló expeditió ügyében Angliában mozgalom indult meg. (...) Miután Gordon az angol politika határozatlanságának áldozatul esett, most az angolok lelkiismereti kötelességnek tartják, hogy megmentsék azon egyetlen európait, ki Afrika szivében a barbárság közepette őrzi a keresztyén kultúra zászlaját."”30 A nyilvánosság mértékét jól mutatja, hogy a Földrajzi Közlemények rögtön négy tervet is közölt „Afrika utazók”-tól, hogy „mely úton mentsék ki kellemetlen helyzetéből Dr. Schnitzlert” (sic!). Stanley „ajánlkozik”, Thompson „ki Masszai országból a Kilimadsaro vidé- 
kéről nem régiben tért vissza hajlandó”, készülődött egy expedíció a Kongó felől, és „Németországban is tervezgetnek”. ${ }^{31}$

A tudományos körök Stanley-vel kapcsolatos hangnemének változása az Equatoriából való hazaérkezése után nem sokkal a Földrajzi Közleményekben is nyomon követhető. 1890-ben Xantus János még „századunk legmerészebb és legtehetségesebb felfedező utazójának" nevezte, ${ }^{32}$ ifjabb Jankó János pedig tudományos, politikai és emberbaráti szempontból is fontosnak értékelte útját (Jankó, 1890: 113). A következő évben azonban már a brit földrajzi körökhöz hasonló elutasító hangok olvashatók ki a Magyar Földrajzi Társaság éves elnöki jelentéséből, miszerint „,nem vitt ő magával semminemü tudományos előkészültséget útjaira, és úgy látszik nem támadt benne bámulatos vándorlásai közben legkisebb szeretet és rokonszenv sem, az alapos kutatás iránt." ${ }^{\prime 3}$ Ezért talán nem véletlen, hogy amikor Stanley végre Budapestre is ellátogatott 1897 Húsvétján, a Társaság elnökségi tagjai azonban „sajnos” - az ünnepek miatt - nem tudták fogadni az utazót. ${ }^{34}$

Stanley és Emin pasa konfliktusa - hasonlóan Stanley és Livingstone összehasonlításához - is inkább Stanley ellen fordította a szélesebb közvéleményt. Stanley felfedezéseit élete vége felé már nyíltan megkérdőjelezték a szakmai körök. ${ }^{35}$ Noha „úttörő" volta miatt érdemei egy részét nem vitatták, 1904-ben bekövetkezett halálakor még mindig tisztázatlanok voltak utolsó útjának körülményei. ${ }^{36}$

Stanley és Emin

Ezer halálos nagy veszély hiába

Stanley bement Eminért Áfrikába.

Emint a szükség, hőség s éh kinozta,

S ezernyi bajból Stanley őt kihozta.

S mikor kihozta, nincs jobb gondja semmi,

Csak, mint lehetne Emint tönkre tenni.

És összevesznek. Furcsa, czéda látvány;

Imé egy éposz, melyben fő a zsákmány.

Stanley a bátor vén basát leszólja,

Ily megmentőktől máskor isten óvja.

De végre vén Emin is visszatámad:

„Mentsd meg te máskor az öregapádat!”

Forrás: Borsszem Jankó. 23. évf., 1162 (16). szám (1890. április 20.), p. 7. 


\section{Jegyzetek}

1 Fodor Ferenc (1887-1962) geográfus 1951-ben készült kézirata Dövényi Zoltán szerkesztésében jelent meg 2006-ban, az MTA Földrajztudományi Intézetének kiadványaként.

2 A Carl Ritter (1779-1859) német földrajztudós nevéhez köthető iskola tagjai szerint a természet és a társadalom szoros kölcsönhatásban áll egymással, amelyben elsősorban a természeti körülmények határozzák meg egy társadalom, illetve kultúra kialakulásának és fejlődésének körülményeit.

3 „A magyar földrajzi társulat tagjai”. Földrajzi Közlemények. 1. évf. (1873), 67-73. pp.

4 „A Magyar Földrajzi Társaság tisztikarának és tagjainak névjegyzéke az 1893. év elején”. Földrajzi Közlemények. 21. évf. (1893), Melléklet.

5 „Tagjegyzék. A Magyarországi Néprajzi Társaság Szervezete”. Ethnographia. 12. évf. (1894), 216-222. pp.

6 „Közintézetek, egyletek”. Vasárnapi Ujság. 20. évf., 7. sz. (1873. február 16.), 85. p.

7 Lásd például Sámi Lajos 1873. december 30-án Alexandrine Tinne utazásairól („Közintézetek, egyletek". Vasárnapi Ujság. 21. évf., 1. sz. (1874. január 4.), 11. p.), vagy 1876. május 25-én Cameron utazásáról tett beszámolóit („Közintézetek, egyletek”. Vasárnapi Ujság. 23. évf., 23. sz. (1876. június 4.), 364. p.).

8 Például Oskar Lenz előadása 1883. március 15-én („Közintézetek és egyletek”. Vasárnapi Ujság. 30. évf., 12. sz. (1883. március 25.), 193. p.).

9 Pédául Oscar Baumann 1893. december 14-én ,a nagy számmal megjelent tagok előtt” tartott előadást. („A főtitkár jelentése 1893. februárhótól - 1894. áprilishó közepéig”. Földrajzi Közlemények. 22. évf. (1894), 209. p.).

10 „Közintézetek, egyletek”. Vasárnapi Ujság. 23. évf., 43. sz. (1876. október 22.), 684. p.

11 „Közintézetek, egyletek”. Vasárnapi Ujság. 24. évf., 17. sz. (1877. április 29.), 268. p.

12 „Közintézetek, egyletek”. Vasárnapi Ujság. 24. évf., 22. sz. (1877. június 3.), 348. p.

13 Czimmermann István (1849-1894) és Menyhárth László (1849-1897) jezsuita misszionáriusok a mai Mozambik területén teljesítettek szolgálatot. Czimmermann István 1885-ben érkezett Afrikába, ahol szolgálatát a boromai misszióban kezdte. 1889-ben visszatért Európába, hogy további misszionáriusokat toborozzon. Visszatértekor Menyhárth László is vele tartott 1890-ben. 1892-ben Zumbóban Czimmermann újabb missziót alapított. Mindketten itt haltak meg, Czimmermann 1894-ben, Menyhárth 1897-ben.

14 „Nemzetközi afrikai társulat”. Földrajzi Közlemények. 6. évf. (1878), 166. p.

15 „A magyar Afrika-bizottság”. Földrajzi Közlemények. 5. évf. (1877), 282. p.

16 „Afrikába sokan vágynak”. Vasárnapi Ujság. 26. évf., 4. sz. (1879. január 26.), 61. p.

17 „A magyar Afrika-bizottság”. Földrajzi Közlemények. 7. évf. (1879), 185-186. pp.

18 „Afrikába!” Vasárnapi Ujság. 26. évf., 7. sz. (1879. február 16.), 108-109. pp.

19 „Afrikába”. Vasárnapi Ujság. 26. évf., 8. sz. (1879. február 23.), 125. p.

20 „Közintézetek, egyletek”. Vasárnapi Ujság. 26. évf., 20. sz. (1879. május 18.), 324. p.

21 „Közintézetek és egyletek”. Vasárnapi Ujság. 24. évf., 5. sz. (1887. január 30.), 80. p. A Bizottság munkáját figyelemmel követő írások szerint többszöri adományt küldtek a nemzetközi társaság részére. /Lásd például „Közintézetek, egyletek”. Vasárnapi Ujság. 24. évf., 43. sz. (1877. október 28.), 683. p., és „Közintézetek, egyletek”. Vasárnapi Ujság. 26. évf., 20. sz. (1879. május 18.), 324. p./ Ezek nagyrészt az elnökségben helyet foglaló arisztokratáktól származtak. Az afrikai eseményeket figyelemmel kísérő lelkes átlagemberek viszont a néhány évvel később meginduló katolikus missziótevékenység támogatásával élhették ki tenni akarásukat és lehettek részesei annak az álomnak, amely Afrika európai civilizálásáról szólt.

22 „Magyar Néprajzi Társaság”. Vasárnapi Ujság. 36. évf., 2. sz. (1889. január 13.), 31-32. pp.

23 Lásd például az Archiv für Anthropologie egyik cikkének kivonatát 1872-ben. („A női mell a vad és müvelt nemzeteknél”. Vasárnapi Ujság. 19. évf., 44. sz. (1872. november 3.), 546 p.).

24 „A Kongo-állam”. Vasárnapi Ujság. 32. évf., 3. sz. (1885. január 18.), 46. p. 
25 „Expedíciók”. Földrajzi Közlemények. 9. évf. (1881), 341. p.

26 „Stanley utócsapatja az Aruvimi mellett”. Vasárnapi Ujság. 37. évf., 48. sz. (1890. november 30.), 782-783. pp.; „A Kongo-vidék emberevő lakosai. Westmark Tivadar úti élményei KözépAfrikában”. Vasárnapi Ujság. 39. évf., 11. sz. (1892. március 13.), 184-186. p.

27 A legsötétebb Afrikában című műve Ráth Mór gondozásában jelent meg először füzetenként 1890. májusától.

28 „Stanley halála”. Vasárnapi Ujság. 34. évf., 30. sz. (1887. július 24.), 506. p.; „Stanley halálának hire nincs megerősitve”. Vasárnapi Ujság. 34. évf., 31. sz. (1887. július 31.), 522. p.; „Stanley”. Vasárnapi Ujság. 34. évf., 35. sz. (1887. augusztus 1.), 586. p.

29 Mehmet Emin Pasa (1840-1892), Isaak Eduard Schnitzerként született a sziléziai Opole városában. 1864-ben szerzett orvosi diplomát, de hivatását nem gyakorolhatta, ezért az Oszmán Birodalom területén igyekezett lehetőségeket keresni: először Montenegró területén, majd Kairóban, végül Kartúmban telepedett le, ahol Charles George Gordon, Equatoria (a mai Dél-Szudán) akkori egyiptomi kormányzója tisztiorvosi állást ajánlott neki. Gordon diplomáciai missziókkal is megbízta, 1878-ban pedig Gordon utódja lett Equatoria kormányzójaként. Equatoriát Muhammad Ahmad (a Mahdi) 1881-ben kezdődő felkelése vágta el a külvilágtól, Emin ekkor vonult az Albert-tó partján fekvő Wadelai-ba (Uganda). Stanley itt talált rá 1888 áprilisában.

30 „Rövid közlemények”. Földrajzi Közlemények. 15. évf. (1887): 66. p.

31 „Rövid közlemények”. Földrajzi Közlemények. 15. évf. (1887): 67. p.

32 „Elnöki megnyitó beszéd. Tartotta Xantus János alelnök az 1890. január 23-iki közgyülésen”. Földrajzi Közlemények. 18. évf. (1890), 3. p.

33 „Az elnök jelentése az utolsó évi földrajzi mozgalmakról”. Földrajzi Közlemények. 19. évf. (1891), 36. p.

34 „Stanley Budapesten”. Vasárnapi Ujság. 44. évf., 17. sz. (1897. április 25.), 273. p.

35 Például a francia Charles Maurice Versepuy 1895-1896-os útja már cáfolja az Albert-tó körüli leírásait. „Rövid közlemények”. Földrajzi Közlemények. 26. évf. (1898): 44. p.)

36 „A földrajz halottai 1904-ben”. Földrajzi Közlemények. 32. évf. (1904), 487. p.

\section{Felhasznált irodalom}

- Driver, Felix (1991): „Henry Morton Stanley and His Critics: Geography, Exploration and Empire”. Past \& Present. Vol. 133., No. 1., 134-166. pp.

- Diver, Felix (2001): Geography Militant. Cultures af Exploration and Empire. Oxford, Backwell.

- Fodor Ferenc (2006): A magyar földrajztudomány története. Az eredeti kézirat alapján sajtó alá rendezte Dövényi Zoltán. Budapest, Magyar Tudományos Akadémia Földrajztudományi Kutatóintézet.

- Kósa László (1989): A Magyar Néprajzi Társaság százéves története (1889-1989). /A Magyar Néprajzi Társaság Könyvtára 7./ Budapest, Magyar Néprajzi Társaság - Kossuth Lajos Tudományegyetem Néprajzi Tanszéke. 
A szerzőröl

MA történelem-néprajz

szak, Pécsi

Tudományegyetem

Bölcsészettudományi Kar

Doktorjelölt, ELTE

Történettudományi

Doktori Iskola

Új-és Jelenkori

Egyetemes Történeti

Doktori Program

\section{About the Author}

MA in History and

Ethnography at the

University of Pécs

Faculty of Humanities

PhD candidate of the

Eötvös Loránd

University Doctoral

School of History

Modern and

Contemporary World

History Doctoral

Programme

@

kicsindi.edina@gmail.com

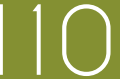

\section{English Abstract}

Scientific disciplines on the brink of specialization and popular culture.

How did the exploration and colonization of Africa in the second half of the 19th century influence the evolution of Hungarian geography and ethnography?

Scientific associations that still exist today were founded all across Europe since the middle of the $19^{\text {th }}$ century. Magyar Földrajzi Társulat (Hungarian Geographical Society; now: Magyar Földrajzi Társaság) was created in 1872, Magyarországi Néprajzi Társaság (Hungarian Ethnographical Society; now: Magyar Néprajzi Társaság) in 1889; but they were different from today's similar organizations in their basic goals, tasks and their membership as well. These associations were "hybrids" of sorts: they possessed both a scientific side and a science-popularizing side that aimed for a large number of members for financial security. The Hungarian Geographical Society used the huge public interest surrounding the exploration of Africa better: inviting explorers returning from Africa, public readings and regular news based on foreign associations' publications served undoubtedly the above mentioned popularizing purpose. However the geographers of the early $20^{\text {th }}$ century voiced harsh critiques against the sensationalism of the Hungarian Geographical Society. At the same time Hungarian geography as a science was not lagging behind that of Western Europe at the time of the explorations. 1870-1880 were the decades of Central African exploration, and the main focus of Western European geographical publications and events as well. The official journal of the Hungarian Ethnographical Society, Ethnographia containing much fewer Africa-centric publications is partly due to the Association having been created at the end of the explorations. However, while Földrajzi Közlemények (the official journal of the Hungarian Geographical Society) followed the political movements of Europe in Africa between 1890 and 1900, even though the time of explorations was over, Ethnographia distanced itself from these in favour for more professional content. Földrajzi Közlemények and Hungarian geography in general only followed suit after 1900. 